\title{
Airport Security Versus Patient Security: The "Sickurity" Problem
}

\author{
Peter P. Felkai
}

Head of Department, Travel Medicine Chair, Internal Medicine Faculty, Debrecen Medical School, Hungary

Corresponding Author: Peter P. Felkai, MD, PhD, Associate Professor, Head of Department, Travel Medicine Chair, Internal Medicine Faculty, Debrecen Medical School, Hungary. Email: peter.felkai@soshungary.hu

Received May 21, 2016; Accepted June 16, 2016; Online Published September 25, 2016

\begin{abstract}
The massive restrain security measurements at the airports very much impress the health status of the healthy and sick passengers alike. The security check is undisputedly a harassment - the confiscation of fluids, the limited movement on the airplane results in a stressful situation and put a harmful effect on healthy traveler and an even more harmful one on the sick. This kind of problem could be called "sickurity" problem. The aim of this article is to estimate the effects of safety measurements on the patients during their medical repatriation by commercial flight. Due to the high level of anti-terrorism measurements, the medical repatriation of a sick traveler has become more difficult than ever. The main issues of the problem are the following: entering with a patient on a stretcher into the security restricted area; taking the medical equipment, tools and drugs of the escorting professionals on the plane; ensuring appropriate oxygenisation in the safety zone, etc.

While the safety measurements and restrictions could interfere with the patient's treatment before and during the fly, the same is true for the medical escort, who need to treat and care the patient before and during the trip. Unfortunately, majority of airports are not prepared to solve this problem. Moreover, the security rules are vary by countries. Eventually the patient security and airport security are not mutually exclusive ideas. The traveller - both healthy and sick - has a right for appropriate care and treatment even at the airport. Therefore uniformised, satisfactory regulations are badly needed in order to remedy this urgent problem - a protocol, which meet the security and the health-care requirements both alike. Hopefully the authorities (IATA, ASMA, local transport authorities) whom may concerned in the topic will realise and soon create a solution to the "sickurity" problem.

Keywords: Medical repatriation, Airport security, Medical escort, Patient safety
\end{abstract}

Citation: Felkai PP. Airport security versus patient security: the "sickurity" problem. Int J Travel Med Glob Health. 2016;4(3):73-75. doi:10.20286/ ijtmgh-040301.

\section{Introduction}

The first attack against an aircraft had already happened six month after the first man-made flying device, De Rozier balloon flew in 1873. An angry young officer intended to cut the mooring ropes of the balloon because his travel was denied. It seems that the aviation security was strained even in the eve of the aviation history. ${ }^{1}$ It can be seen that the problem of aviation security has been in existence from the very beginning of aviation history.

The first terrorist attack against a Canadian aircraft in the early 1940s resulted that the Chicago Convention ${ }^{2}$ obliged all member states to establish a national authority to devise a security program to prevent dangerous objects being brought on board. " "Modern" or international terrorism began in 1968 with attacks against Israeli airplanes. ${ }^{4}$ This terrorism was triggered by the tension in the Middle East, the struggle between right- and left-wing ideologies, and crisis situations in ethnic, nationalist, and religious struggles. The first security measure involved improved checking of luggage, and suspected explosives were often found in unattended

\section{baggage. ${ }^{5}$}

The regulations at that time assumed that terrorists did not want to die. That was a reasonable hypothesis until the tragedy in Lockerbie in 1988. As a result, the International Civil Aviation Organization (ICAO) suggested stronger security measures for the screening of passengers, luggage, and cargo. ${ }^{6}$ With the emergence of suicide terrorists, this theory was abandoned. Additional steps in security involved checking $\mathrm{x}$-ray devices, metal sensor gates, and automatic equipment for the detection of explosives. The attack against the World Trade Center in 2001 has had a great impact on the tourism industry. ${ }^{7}$ This attack radically changed security measures and the attitude towards passengers, their rights to privacy, and the safety of sensitive data. An almost hysterical safety attitude has emerged, and security checks are often based on an emotional approach, rather than evidence-based screening. Full-body screening is widely accepted and is practiced under suspicious circumstances. ${ }^{8}$ In addition, the 9/11 events raised the question of air safety to the political agenda of the EU Council. A common EU standard was adopted and safety

Copyright $(\odot 2016$ The International Journal of Travel Medicine and Global Health. This is an open-access article distributed under the terms of the Creative Commons Attribution License (http://creativecommons.org/licenses/by/4.0), which permits unrestricted use, distribution, and reproduction in any medium, provided the original work is properly cited. 
issues became part of the EU transportation policy. ${ }^{9}$

In 2006, police in London discovered a so-called liquid bomb. It was alleged that the bomb was destined to blow up a transatlantic aircraft. Although the events and the real danger of a liquid bomb were controversial, the consequences were serious. The passenger should not bring more than 100 $\mathrm{mL}$ fluids through the security check-points, and any LAG materials (liquid, aerosol, gel) are considered dangerous and - consequently - prohibited items. Gate checkpoints was implemented in the United States, because the passengers could buy some beverages in the secure zone of the airport, too. ${ }^{10}$ Baggage size was restricted to $56 \times 45 \times 25 \mathrm{~cm}$. The EU Parliament confirmed this type of restriction ${ }^{11}$ and allowed for the presence of air marshals on airplanes, which has been routine on US airlines since 1963. An EU regulation was also issued concerning disabled persons. ${ }^{12}$ In this regulation, similar to previous regulations, there is no mention of sick passengers or repatriation, accompanying medical personnel, and their equipment. The illness itself is rarely mentioned among the travelers' complaints; it is usually forgotten or becomes a story of the adventure. ${ }^{13}$ Yet, some kinds of illnesses are an indication for breaking the journey, and the returning or repatriation of the traveler may be needed.

\section{Repatriation of Stretcher Patients on Regular Flights}

The patient transportation on stretcher for a long haul trip is rather costly. The most economical way is proved to be the repatriation by regular flight, where the stretcher located above six or more row of seats. The stretcher patient must be escorted by medical staff. The patient and the staff is taken to the airport by an ambulance, but the ambulance must not enter the security zone. Thus the patient must be transposed into the ambulance of airport medical service (AMS), from AMS ambulance into the medilift which elevated the stretcher up to the cabin level, and from medilift to the stretcher of the aircraft. ${ }^{14}$ The multiple transposition causes a so-called transportation trauma and could cause pain and circulation disturbances. ${ }^{15-18}$ The situation of the patient in vacuummattress is even worse.

There is probably only one medically acceptable solution to this problem; the stretcher from the regular ambulance should be taken directly to a medical lift in the airport and the same process should occur at the destination. On-site screening of the medical escort should not be a problem. ${ }^{19}$ The repatriation organizing company often faces challenges caused by a lack of direct flights from the evacuation site to the destination. This interruption of medical repatriation involves four extra movements for the patient. The medical room for civilians within the airport security area should not be merely a quarantine room; the medical room should be appropriately equipped with food and drinking water and communication facilities. Unfortunately, only a few airports have such amenities. The treatment and care of the repatriated patient is the exclusive task of the medical escort, and obviously they need their medical equipment, medicines and tools. This could be the next "sickurity" problem.

\section{Is the Escorting Physician a Security Risk?}

In the case of medical repatriation on a commercial flight, a nurse or physician escort usually has to accompany and observe the patient during the repatriation process. Medical escorts must carry appropriate equipment (defibrillator, battery operated suction and infusion pumps) which could be suspicious. The most pharmaceuticals contain "dangerous" raw materials, the vital fluids (infusions) usual volume are more than the permitted $100 \mathrm{~mL}$, gels and aerosols are common in a doctor's case and the surgical devices (forceps, scalpel, needles) could also considered as dangerous objects. All the portable medical devices (infusion pump, defibrillator, monitor, insulin pumps, etc.) work by battery and contain electrical circuits. If the authorities at the airport take the plunge to buy equipment with advanced technology the medical substances could be checked and could be identified without breaking their sterility. ${ }^{20}$ All the medical equipment if they are approved for in-flight use, are should be considered safe from a point-of-view of aviation security. ${ }^{21}$

In theory, under air terminal regulations, a person can be exempted from the requirements, ${ }^{22}$ such as a valid airport ID, and obligatory background checks on the condition that he/she is escorted during his/her stay in the security restricted area (SRA). Exceptions could be made by the local authority in question if they are willing to do so; nevertheless, this treatment is not possible for any other party, including authorities in another airport or the captain of an aircraft. Therefore, it is assumed that medical escorts can leave their homeland with medical equipment, but there is no guarantee that they can board with the patient on return. ${ }^{23}$

The use of an on-board medical emergency kit might seem to be a solution, but such equipment is inappropriate. First, the kit is not intended for advanced or tailored patient care, but for in-flight emergencies only. Second, the kit is only available on board the airplane. All through the journey to the airport and transfer onto the airplane, appropriate equipment and medical instruments are important. When a patient needs oxygen supply, the escorting medical staff should carry an extra bottle of oxygen to avoid the "checkin oxygen gap." Carrying any oxygen cylinder, which does not belong to the air company is highly prohibited on board an aircraft. Unfortunately, the portable oxygen concentrator cannot solve the problem in most cases due to the fact that it is unable to maintain reduced oxygen flow or $\mathrm{FiO}_{2} \cdot{ }^{24,25}$ Medical certificates are mandatory only if a patient requires a stretcher or wheelchair to the aircraft seat. ${ }^{26}$

\section{Conclusion}

Despite the threat of terrorism, pandemics, and natural disasters, worldwide travel is booming. The incidence of travel-related medical problems and consequently the number of repatriations will increase with the number of travelers. Recent safety regulations make medical repatriation difficult. Majority of repatriations occur on regular flights. Patients with minor medical problem or injuries of the upper extremities can easily travel and often require only the use of a wheelchair at the airport. There is no problem when a critically ill patient is repatriated by air ambulance because aircraft usually wait outside the SRA. In contrast, stretcher patients and their medical escorts can pose security risks. Even if local (domestic) authorities co-operate in overcoming the security problems, other authorities will not necessarily do so. 
The problems relating to patient transport and movement and the carrying of necessary medical equipment require a satisfactory solution and standard procedures. An international protocol is necessary to avoid security problems without affecting the patient's interests. Competent medical suggestions by travel medicine specialists, aviation medicine professionals, and insurance physicians would surely help lawmakers in working out appropriate regulations in this particular field. Unfortunately, the legislative route is long and bureaucratic. The authority in an International Air Transport Association member state must submit a proposal on a particular topic before the ICAO would follow its normal process to create standards and recommended procedures. Skepticism could hamper the effectiveness of debating the issue in medical circles; it might seem that the process is merely a paperwork exercise by the authorities and not a matter for medical circles.

\section{Conflict of Interest Disclosures}

No conflict of interest.

\section{Ethical Approval}

There is no any ethical aspect of the article.

\section{Funding/Support}

None.

\section{Acknowledgments}

None.

\section{References}

1. Shampo MA, Kyle RA. Jean Francois Pilatre de Rozier. JAMA. 1983;249(16):2203. doi:10.1001/jama.249.16.2203

2. FitzGerald GF. The Development of the authentic trilingual text of the Convention on International Civil Aviation. Am J Int Law. 1970;64(2):364-371.

3. The Convention on International Civil Aviation. Security: Safeguarding International Civil Aviation Against Acts of Unlawful Interference, Annex 17. Published July 2006.

4. Jenkins BM, Johnson J. International Terrorism: A Chronology, 1968-1974. DTIC Document; 1975.

5. Mueller O, ed. New ways of explosive booby traps at the international terroristic actions. Security Technology, 1993 Security Technology, Proceedings Institute of Electrical and Electronics Engineers 1993 International Carnahan Conference on; 1993: IEEE.

6. Bramham G. ICAO eight-point plan adopted in 1989 has strengthened aviation security. ICAO J. 1998;53(10):4-6.

7. Goodrich JN. September 11, 2001 attack on America: a record of the immediate impacts and reactions in the USA travel and tourism industry. Tourism Manag. 2002;23(6):573-580. doi:10.1016/ S0261-5177(02)00029-8

8. Levine S. Intrusive airport searches: screeners authorized to "pat down" private parts. US News and World Report; 2004.

9. Treaty on European Union. Official Journal C 191, 29 July 1992.

10. Hauser C. US eases rules on carry-on luggage. The New York Times. August 13, 2006.

11. Commission Regulation (EU) No. 185/2010 of 4 March 2010 laying down detailed measures for the implementation of the common basic standards on aviation security (Official Journal L 055, 05/03/2010 P. 0001-0055). 2010.

12. Regulation EC No. $1107 / 2006$ on the rights of disabled persons and persons with reduced mobility when travelling by air. Published 2006.

13. Chris R. Recreational Tourism: A Social Science Perspective. London: Routiedge; 1991.

14. Felkai P, Gorove L. Repatriation of the traveler, falling ill abroad (A külföldön megbetegedettek hazaszállítása). Orv Hetil. 2009;150:1669-1676.

15. Wang H, Weaver M, Abo B, Kaliappan R, Fairbanks RJ. Ambulance stretcher adverse events. Qual Saf Health Care. 2009;18(3):213216. doi:10.1136/qshc.2007.024562

16. Knapik JJ, Harper W, Crowell HP. Physiological factors in stretcher carriage performance. Eur J Appl Physiol Occup Physiol. 1999;79(5):409-413. doi:10.1007/s004210050530

17. Knapik J, Harper W, Crowell H, Leiter K, Mull B. Standard and alternative methods of stretcher carriage: performance, human factors, and cardiorespiratory responses. Ergonomics. 2000;43(5):639-652. doi:10.1080/001401300184305

18. Sagawa K, Inooka H. Ride quality evaluation of an activelycontrolled stretcher for an ambulance. Proc Inst Mech Eng $\mathrm{H}$. 2002;216(4):247-256. doi:10.1243/09544110260138736

19. Felkai P. Airport security check of medical substances used during patient repatriation. [A beteg hazaszállítása alatt használt orvosi anyagok repülőtéri biztonsági vizsgálatának lehetőségei]. Orv Hetil. 2012;153(37):1469-1474. doi:10.1556/OH.2012.29433.

20. Basic consideration on the security checking of sick travelers at airports. [A beteg utazók repülőtéri biztonsági vizsgálatának alapelvei] Orv Hetil. 2012;153(35):1380-4. doi: 10.1556/ OH.2012.29437.

21. Bristow A, Toff NJ. A report-recommended standards for UK fixed wing medical air transport systems and for patient management during transfer by fixed wing aircraft. J R Soc Med. 1992;85(12):767.

22. Commission Regulation (EU) No. 185/2010 of 4 March 2010. Laying down detailed measures for the implementation of common basic standards on aviation security, Annex 1, point 1.2.7.2. Published 2010.

23. Felkai P. Are the flight security measures good for the patients? The "sickurity" problem (Repülötéri biztonság kontra betegbiztonság? a "sickurity" problémája). Orv Hetil. 2010;151(41):1702-1707. doi:10.1556/OH.2010.28973.

24. Rodriquez D Jr, Blakeman TC, Dorlac W, Johannigman JA, Branson RD. Maximizing oxygen delivery during mechanical ventilation with a portable oxygen concentrator. J Trauma. 2010;69(1):S87-S93. doi:10.1097/TA.0b013e3181e44b27.

25. Akerø A, Edvardsen A, Christensen CC, Owe JO, Ryg M, Skjønsberg $\mathrm{OH}$. COPD and air travel: oxygen equipment and preflight titration of supplemental oxygen. Chest. 2011;140(1):84-90. doi:10.1378/ chest.10-0965.

26. Brunette GW, Kozarsky P, Magill AJ, Shlim DR. CDC Health Information For International Travel 2010. Edinburgh: Mosby; 2009. 